\title{
Comparison among Cornelian Cherry and Prunus cerasus According to Phenolic Content and Antioxidant Capacity by Three Various Methods of Extraction
}

\author{
Newshan Behrangi', Hossein Ghafoori², Zeinab Farahmand ${ }^{3}$, Elham Mohammad Khani ${ }^{3}$, \\ Mohammad Hossein Sanati ${ }^{3,4^{*}}$ \\ ${ }^{1}$ Faculty of Basic Sciences and Advanced Technologies in Biology, University of Science and Culture, Tehran, \\ Iran \\ ${ }^{2}$ Department of Biology, University of Guilan, Rasht, Iran \\ ${ }^{3}$ Iranian Biological Resource Center, Tehran, Iran \\ ${ }^{4}$ National Institute of Genetic Engineering and Biotechnology, Tehran, Iran \\ Email: ${ }^{*}$ mhsanati@yahoo.com
}

Received 18 May 2015; accepted 25 September 2015; published 28 September 2015

Copyright $@ 2015$ by authors and Scientific Research Publishing Inc.

This work is licensed under the Creative Commons Attribution International License (CC BY).

http://creativecommons.org/licenses/by/4.0/

(c) (;) Open Access

\begin{abstract}
Cornelian cherry and Prunus cerasus with red pigments possess precious source of flavonoids and phenolic acids which have various applications in treatment of various health problems. This study is conducted to compare different methods of extraction (shaking incubator, soxhelet, ultrasonic) were applied in order to identify the best method which shows the highest rate of antioxidant capacity by DPPH and ferric reducing antioxidant power (FRAP) methods and total phenolic compounds via Folin-Ciocalteu procedure, p-coumaric acid content of fruits were evaluated by high performance liquid chromatography (HPLC). As a result, cornelian cherry with 1313.13 $\mathrm{mg} / \mathrm{Kg}$ average TPC score exhibits higher total phenolic content than Prunus cerasus with 1270 $\mathrm{mg} / \mathrm{Kg}$. It's notice worthy that there was a slight difference among antioxidant activity in two fruits. Consequently, DPPH revealed nearly stronger antioxidant activity for Prunus cerasus while cornelian cherry had a little more potent antioxidant activity according to FRAP Test. p-coumaric acid content was almost twice in Prunus cerasus $(10.8 \mathrm{mg} / \mathrm{ml})$ than cornelian cherry $(5.6 \mathrm{mg} / \mathrm{ml})$. In addition, both shaking incubator and ultrasonic extraction procedures were more efficient than soxhelet in two fruits.
\end{abstract}

${ }^{*}$ Corresponding author.

How to cite this paper: Behrangi, N., Ghafoori, H., Farahmand, Z., Khani, E.M. and Sanati, M.H. (2015) Comparison among Cornelian Cherry and Prunus cerasus According to Phenolic Content and Antioxidant Capacity by Three Various Methods of Extraction. Food and Nutrition Sciences, 6, 1166-1173. http://dx.doi.org/10.4236/fns.2015.612122 


\section{Keywords}

\section{Cornelian Cherry, Prunus cerasus, p-Coumaric Acid, Total Phenolic Content, Antioxidant Activity}

\section{Introduction}

Fruits with red pigments possess precious source of flavonoids and phenolic acids which have various applications in treatment of cancer and neurodegenerative diseases. Cornelian cherry (Cornus mas) is a species of flowering plant in dogwood family, is native to eastern Europe, Mediterranean countries (Italy, Spain) abundant in southern Belgium Luxemburg, central Germany, Middle eastern Asia (Turkey, Iran) central Asia, and south America [1]. Cornus mas is an excellent source of phenolic compounds (anthocyanin, flavonoids), antioxidants (butyl hydroquinone, butylated hydroxyanisole, and butylated hydroxytoluene) [2], high content of vitamins (E, B2, B1, and C), minerals $\left(\mathrm{K}^{+}, \mathrm{Ca}^{2+}, \mathrm{Mg}^{2+}, \mathrm{Fe}^{2+}, \mathrm{Zn}^{2+}, \mathrm{Mn}^{2+}, \mathrm{Cu}^{2+}, \mathrm{Na}^{+}\right)$[3]. According to previous research, cornus juice is made up $10 \%$ tannins, $10 \%$ sugar, $5 \%$ pectin, $3 \%$ malic acids, $2 \%$ amberic acids, $1 \%$ ascorbic acids, glycosides, cartenoids, essential oils, and it has shown that the rate of Ascorbic acid in cherry is more than orange [1]. It's notice worthy that different parts of this plant (bark, leaves, and ripe fruit) have health benefits, for instance: all parts of plant have astringent properties [4], fruits are consumed to alleviate diarrhea and dysentery, sore throat, digestion problems, measles, chicken pox, anemia, diabetes [1]. In addition, flesh of fruit and seed oil is consumed for recovery and regeneration of damaged inner and outer epidemic tissues. A tincture that is made by the bark or the leaves of the plant can treat some health problems, for example: eczema, skin infection, intestinal parasites, veal skins, and gout [5]. Previous research has demonstrated cardio-tonic, anti-inflammatory and antioxidant, antidiabetic, anti-obesity activity of cornelian cherry [6] [7], it is proposed that different benefits of cornelian cherry are due to variety of phenolic acids, flavonoids, anthocyanin agents [8].

Prunus cerasus is a species of Prunus in the subgenus Cerasus (cherries) has different names: tart cherry, pie cherry, morello cherry, red cherry or sour cherry and is generated from hybridization between Prunus avium (sweet cherry) and Prunus fruticos (European dwarf cherry) in northern Iran and Turkmenistan, originated firstly from this place, has spread in Europe, and currently is cultivated in US [9]. Tart cherry is valuable source of vitamins (A, B1, B2, C, E, K, and Niacin), cartenoids like beta-carotene, minerals $\left(\mathrm{Ca}^{2+}, \mathrm{Fe}^{2+}, \mathrm{K}^{+}, \mathrm{Na}^{+}, \mathrm{Mn}^{2+}\right.$, and Phosphorous) [10], fiber, various suger like Fructose, Glucose, Maltose, antioxidant agents such as Caffeicacids, p-Coumaric acids, 1-(3',4'-dihydroxycinnamoyl)-cyclopenta-2,5-diol,1(3',4-dihydroxycinnamoyl)-cyclopenta-2,3-diol, cyaniding-3-O-glucosylrutinoside [11] [12].

Prunus cerasus has some health benefits, including: decrease body weight and blood cholesterol of diabetic patients [13], antioxidant and anti-inflammatory effects [14]-[16], control the sleep-wake-cycle [10], reducing muscle pain [17] and prevent from symptoms of muscle damages [18].

The aim of this study is comparing different methods of extraction were applied for cornelian cherry and Prunus cerasus in order to compare extraction procedures and identify the best method which shows the highest rate of antioxidant activity and total phenolic compounds that save greater amount of beneficial agents in fruits. In addition, content of p-coumaric acid is evaluated by HPLC method in order to determine richer source of this beneficial agent among two precious fruits.

\section{Material \& Method}

Chemicals: Gallic acid, Ascorbic acid, p-coumaric acid, DDPH (2, 2'-diphenyl-1-picrylhydrazyl), NaAC, $\mathrm{FeSO}_{4}$ were purchased from Sigma-Aldriche company. TPTZ, $\mathrm{FeCl}_{3}$, Acetic acid and Methanol $100 \%$ were prepared from Merck company in Germany.

\subsection{Extraction Methods}

Shaking Incubator: Firstly, fruit was bought from market and stored in $-20^{\circ} \mathrm{C}, 5 \mathrm{~g}$ of fruit was measured by measurement with accuracy 0.001 and crushed by mortar. Then, $50 \mathrm{ml}$ methanol $100 \%$ was added and the mixture was poured into bottle and put it into shaking incubator with speed $150 \mathrm{rpm}$ at $40^{\circ} \mathrm{C}$ for $24 \mathrm{~h}$. Finally, the extract was filtered. 
Soxhelet Extractor: $5 \mathrm{~g}$ of fruit was measured and crushed, then it was packed into paper and put into soxhelet device. Candidate solvent was $50 \mathrm{ml}$ methanol $100 \%$ and temperature was set on $80^{\circ} \mathrm{C}$. After, the mixture was poured into rotator evaporator balloon and it was evaporated to $50 \mathrm{ml}$ at $40^{\circ} \mathrm{C}$ with $75 \mathrm{rpm}$.

Ultrasonic Procedure: $5 \mathrm{~g}$ of fruit was measured, crushed and mixed with $50 \mathrm{ml}$ methanol and put the mixture into ultrasonic device. The temperature was set at $40^{\circ} \mathrm{C}$ for 30 min then filtered.

\subsection{Total Phenol Content}

Total phenol method was applied according to Folin-Ciocalteu procedure. Standard for this assay is Gallic acid, $1 \mathrm{mg} / \mathrm{ml}$ Gallic acid/distilled water was prepared, by rising the concentration of St from 10 to $60 \mu \mathrm{l}$, the color ofcomplex would be from yellow to green and the rate of absorbance would be increased. For measuring TPC of fruit sample, five dilution (50, 70, 90,110, $130 \mu \mathrm{l})$ of three types of fruit extraction method were analyzed, as an example for preparing aliquots $(50 \mu \mathrm{l})$ fruit extract, $(450 \mu \mathrm{l})$ distilled water and (500 $\mu \mathrm{l})$ Folin-Ciocalteu were mixed and after $3 \mathrm{~min}, 500 \mu \mathrm{l}$ Sodium Carbonate $(0.1 \mathrm{~N})$ was added to mixture, was placed $30 \mathrm{~min}$ in the dark at room temperature. Finally, the absorbance of prepared mixture against the blank at $765 \mathrm{~nm}$ was read by UV-Vis spectrophotometer. The results were expressed by g Gallic acid.

\subsection{Antioxidant Activity}

Antioxidant activity of sample were analyzed by applying two methods: DPPH, FRAP

DDPH (2, 2'-diphenyl-1-picrylhydrazyl) is a free radical scavenging assay that is on basis of transferring electron to produce free radicals. Hence, free radicals are reduced in the presence of antioxidant molecules because antioxidant agents act as $\mathrm{H}$ donor. Consequently, the rate of absorption in DPPH solution would be reduced by increasing the rate of antioxidant activity. $19.7 \mathrm{mg}$ DPPH was measured and solute in methanol to reach $50 \mathrm{ml}$. The standard for this experiment is Ascorbic acid ;therefore, $17.5 \mathrm{mg}$ Ascorbic acid/ distilled water was prepared, three dilution of standard (2, 5, $10 \mu \mathrm{l})$ were mixed with $350 \mathrm{ml} \mathrm{DPPH}$ and reached at $2 \mathrm{ml}$ with methanol, calibration curve was drawn to achieve standard formulation. IC $_{50}$ values attribute to the concentration of the test samples providing 50\% radical scavenging were obtained from graph-plotted scavenging percentage against extract concentration.

$$
\% \text { Inhibition }=\mathrm{A}_{\mathrm{DPPH}}-\mathrm{A}_{\text {Sample }} / \mathrm{A}_{\mathrm{DPPH}} \times 100
$$

For evaluating $\mathrm{IC}_{50}$ of sample, five dilution of cornelian cherry extraction $(10,20,30,40,50 \mu \mathrm{l})$ were applied then $350 \mathrm{ml}$ DPPH was added, then whole mixture was reached to $2 \mathrm{ml}$ by methanol, was placed in dark at room temperature for $30 \mathrm{~min}$ and observed by UV-Vis spectrophotometry. The absorbance of prepared mixture against the blank at $517 \mathrm{~nm}$ was read by UV-Vis spectrophotometer. The results were expressed by g Ascorbic acid.

\subsection{FRAP}

FRAP (Ferric reducing/antioxidant power) is a simple assay that estimates antioxidant capacity of supplements containing polyphenols. For preparing FRAP solution, three different solute should be made. 1) $146 \mu$ l HCL was added to $100 \mathrm{ml}$ distilled water, then $93 \mathrm{mg}$ TPTZ was added to $30 \mathrm{ml}$ of this solute. 2) $162 \mathrm{mg} \mathrm{FeCl}_{3}$ was added to $30 \mathrm{ml}$ distilled water. 3) $930 \mathrm{mg} \mathrm{NaAC}$ was added to $4.8 \mathrm{ml}$ Acetic acid, and reached to $300 \mathrm{ml}$ by distilled water. It is notice worthy that PH of solution must be set at 3.6 by $\mathrm{HCl} 37 \%$. As a result, FRAP solute is composed of $300 \mathrm{ml}$ Acetic acid solute, $30 \mathrm{ml}$ TPTZ, $30 \mathrm{ml} \mathrm{FeCl}$ solute, $36 \mathrm{ml}$ distilled water. Therefore, below reaction would be happened in FRAP solution that can be visualized at $593 \mathrm{~nm}$ by UV-Vis spectrophotometry:

$$
\mathrm{Fe}^{3+}+\mathrm{TPTZ}+\text { antioxidant } \rightarrow \mathrm{Fe}^{2+}+\mathrm{TPTZ}
$$

The standard for this experiment is $\mathrm{FeSO}_{4}$; therefore, $0.0139 \mathrm{~g} \mathrm{FeSO}_{4}$ as standard (st) was measured and mixed with $50 \mathrm{ml}$ distilled water, five dilution of st (10, 20, 30, 40, and $50 \mu \mathrm{l})$ mixed with $1300 \mu \mathrm{l}$ FRAP solution and mixture was reached at $1500 \mu$ final volume by distilled water, calibration curve was drawn to achieve standard formulation. Then, three dilution of fruit sample (5, 10, and $15 \mu \mathrm{l})$ were added to $1300 \mu \mathrm{l}$ FRAP solution, then mixture was reached at $1500 \mu$ final volume by distilled water, and stored at room temperature in dark for $30 \mathrm{~min}$, the absorbance of prepared mixture against the blank at $593 \mathrm{~nm}$ was read by UV-Vis spectro- 
photometer. The results were expressed by g $\mathrm{FeSO}_{4}$.

\subsection{HPLC}

In this experiment, $5 \mathrm{~g}$ of fruit sample was measured, crushed. $0.08 \mathrm{~g}$ Ascorbic acid was dissolved in $5 \mathrm{ml}$ water, then crushed fruit and mixed with $25 \mathrm{ml}$ methanol. Next, $3.5 \mathrm{ml}$ HCL 37\% dissolved in $30 \mathrm{ml}$ water to achieve HCL $1.2 \mathrm{~mol}$. The solution was put on water bath for $16 \mathrm{~h}$ at $35^{\circ} \mathrm{C}$. After staying in room temperature, the solution was filtered and evaporated to dryness by evaporator rotary at $35^{\circ} \mathrm{C}$. It's notice worthy due to existence of some oil in extract, the residue will be one drop of oil after dryness. The residue dissolved in $2 \mathrm{ml}$ methanol and filtered by Whatman ${ }^{\circledR} \mathrm{GD} / \mathrm{X}$ syringe filters with pore size $0.45 \mu \mathrm{m}$, diam $13 \mathrm{~mm}$ for HPLC injection. The HPLC that exploited for this research was equipped with Agilment 1200 series (Agilent technologies Walbronn, Germany). It is consisted of a G1312B binary pump, a G1376A capillary pump, G1330B FC/ALS, G1379B Degasser, and G1377A microwips, controlled by Chemstation software. Chromatographic separations were conducted on columns with $4.6 \times 150 \mathrm{~mm}, 5 \mu \mathrm{m}$ ZORBAX Eclipse XDB C18 column (Agilent technology, Germany). Standard and extracts were run by two mobile phases: A) $0.1 \%$ phosphoric acid, B) (Methanol HPLC 100\%). $10 \mu \mathrm{l}$ standard (1 ppm) and extract should be injected into HPLC. The peak p-coumaric acid was revealed at $320 \mathrm{~nm}$ UV-Vis spectra.

\section{Results}

According to Table 1, two fruits with three various methods of extraction exhibited the rate of total phenol from at least $870 \pm 64$ to $1650 \pm 330 \mathrm{mg} / \mathrm{kg}$. By comparing the content of phenolics on basis of fruits, it is deduced that cornelian cherry with higher average TPC has almost higher total phenolic compounds than Prunus cerasus. In relation to extraction methods, shaking incubator and ultrasonic both revealed higher rate of total phenol than soxhelet in two fruits.

Second and third columns are related to antioxidant activity of fruits (DPPH, FRAP). There is a negative relationship among the score of DPPH score and antioxidant activity. Thus, by comparing two fruits, it is deduced that Prunus cerasus with $6.2 \mathrm{mg} / \mathrm{ml}$ DPPH total average score has almost stronger antioxidant activity than cornelian cherry. Likewise TPC evaluation, shaking incubator and ultrasonic are more efficient approaches for antioxidant activity in regard to their lower $\mathrm{IC}_{50}$ score than soxhelet.

On the basis of FRAP's results, the antioxidant activity of three methods weren't so much different in cornelian cherry; However, ultrasonic method exhibited higher FRAP score than other methods and according averages concluded that cornelian cherry has stronger antioxidant activity than Prunus cerasus that isn't in accord of DPPH result.

HPLC: p-coumaric acid was distinguished by exploiting HPLC procedure to determine quantity of this agent in two fruits. p-coumaric acid was detected at Ret time 17.985, $320 \mathrm{~nm}$ HPLC running and the graphs are shown in Figure 1 and the concentration of agent in fruits are exhibited in Table 2. According to Table 2, averageagent concentration was about $5.6 \mathrm{mg} / \mathrm{kg}$ and $10.8 \mathrm{mg} / \mathrm{kg}$ in cornelian cherry and Prunus cerasus, respectively.

Table 1. Concentration of total phenols (TP) [mg GAE kg-1], and antioxidant activity of fruits by two methods DPPH $\left[\mathrm{mg} \cdot \mathrm{ml}^{-1}\right]$, FRAP $\left[\mu \mathrm{mol} \cdot \mathrm{g}^{-1}\right]$, and three various methods of extraction. Values are means \pm SD $(\mathrm{n}=4)$.

\begin{tabular}{cccc}
\hline Cornelian cherry & $\boldsymbol{\Sigma}$ Polyphenols $\mathrm{mg} / \mathrm{kg}$ & DPPH $\left(\mathbf{I C}_{\mathbf{5 0}}\right) \mathrm{mg} / \mathrm{ml}$ & FRAP $\mu \mathrm{mol} / \mathrm{g}$ \\
\hline Shaking incubator & $1650 \pm 330$ & $3.95 \pm 0.18$ & $190 \pm 20$ \\
Soxhelet & $870 \pm 64$ & $9.67 \pm 2.8$ & $200 \pm 50$ \\
Ultrasonic & $1420 \pm 119$ & $6.43 \pm 0.34$ & $190 \pm 20$ \\
Total average & 1313.3 & 6.68 & 193.3 \\
Prunus cerasus & & & $170 \pm 20$ \\
Shaking incubator & $1260 \pm 310$ & $5.85 \pm 1.18$ & $170 \pm 40$ \\
Soxhelet & $1080 \pm 180$ & $8.13 \pm 0.89$ & $200 \pm 20$ \\
Ultrasonic & $1470 \pm 70$ & $4.70 \pm 1.23$ & 180 \\
Total average & 1270 & 6.2 & \\
\hline
\end{tabular}


Table 2. Concentration of p-Coumaric acid in cornelian cherry and Prunus cerasus (mg.kg ${ }^{-1}$ of fresh weight) determined by HPLC method and concentration of agent is higher in Prunus cerasus. Values are means \pm SD $(n=3)$.

\begin{tabular}{cc}
\hline Fruits & p-Coumaric acids concentration mg/kg \\
Cornelian cherry & 5.6 \\
Prunus cerasus & 10.8 \\
\hline
\end{tabular}

p-Coumaric acid
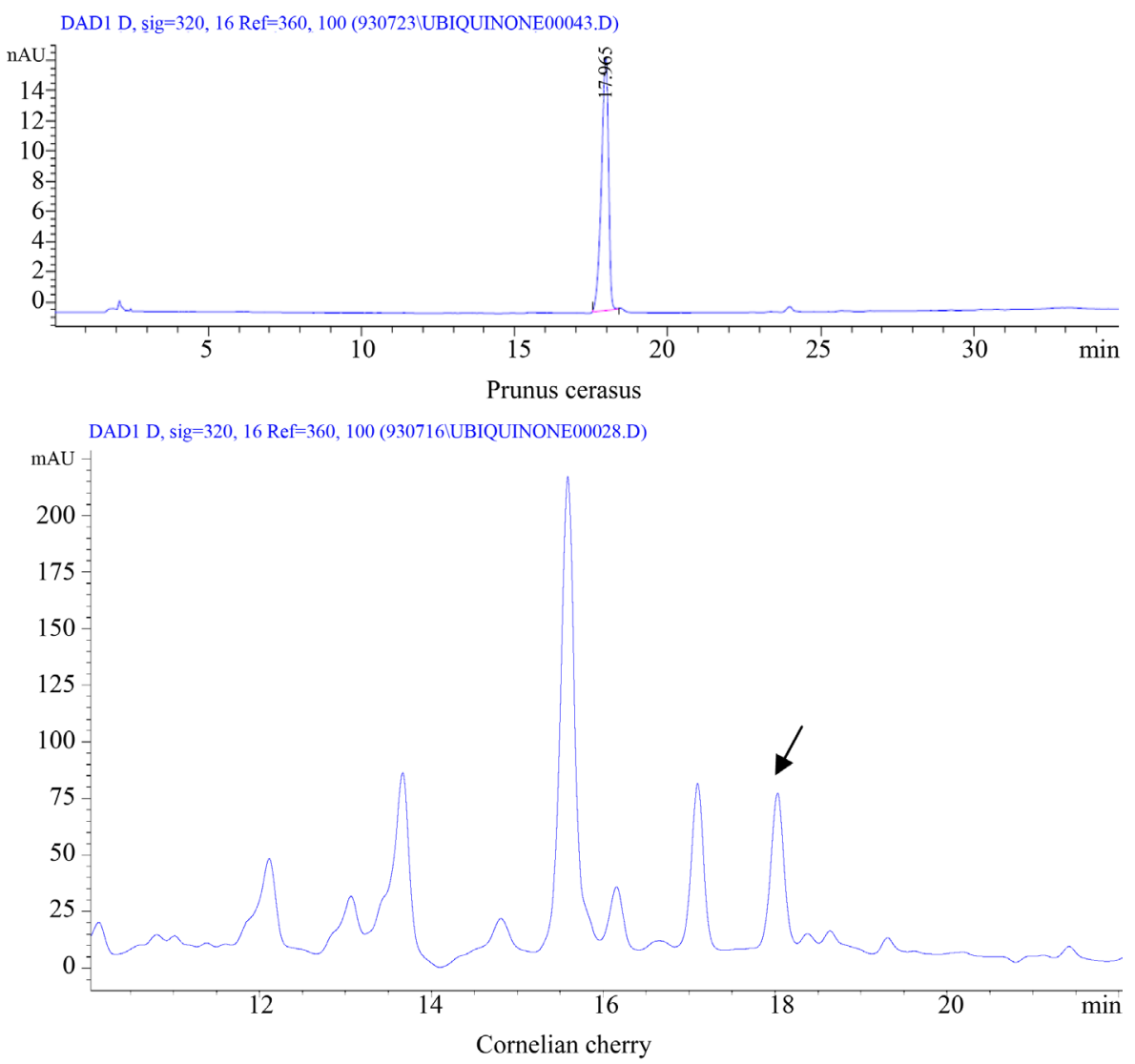

DADI D, sig=320, 16 Ref=360, 100 (930715 \UBIQUINONE00023.D)

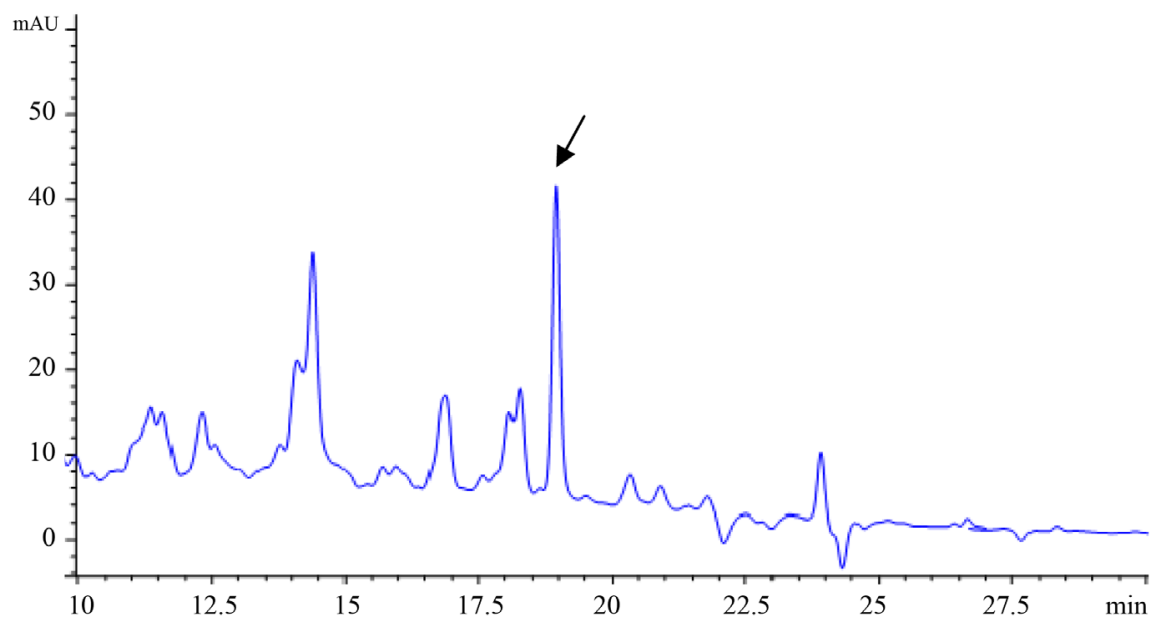

Figure 1. HPLC chromatograph of p-coumaric acid, Prunus cerasus and cornelian cherry that were detected at ret time $17.985 \mathrm{~min}, 320 \mathrm{~nm}$. 
Indeed, the content of p-coumaric acid is higher in Prunus cerasus.

\section{Discussion}

Total phenolic content score is versatile on basis of fruit type, stage of growth, farm of landing, extraction method, component of TPC experiment and other factors. Therefore, by comparing light yellow blush, light red and dark red of cornelian fruit total phenol content researchers found that by transforming fruit from first stages of growth to fully ripe form, the content of total phenol has decreased. Thus, dark fruit with $4162 \mathrm{mg} / \mathrm{kg}$ TPC had the lowest phenolic content, light yellow fruit with $8033 \mathrm{mg} / \mathrm{kg}$ was the richest phenolic compound source [19]. In regard to our study, the content of phenolics are about $1313.13 \mathrm{mg} / \mathrm{kg}$ that is almost 3 times less than reported TPC. In addition, another research conducted in Turkey to evaluate cornelian cherry properties, TPC reported for cornelian cherry was about $2810 \mathrm{mg} / \mathrm{kg}$ that was twice our reported TPC [8]. Another research did a comparison among partially and fully ripetart cherry fruit and concluded that by increasing the ripeness, the distribution of phenolic compounds will be increased. Consequently, fully ripe fruit with $3110 \pm 44 \mathrm{mg} / \mathrm{kg}$ has higher TPC than partially ripe fruit (2170 $\pm 50 \mathrm{mg} / \mathrm{kg}$ ) [20]. Although the tart cherry was applied in our study was fully ripened, the content of TPC was lower than reported TPC for ripefruit. Another study compared TPC of sweet and sour cherry and they found about TPC for sour cherry has spectra from 1461 to $3124 \mathrm{mg} \mathrm{GAL/g}$ that is compatible with our results [21].

DPPH activity of cornelian cherry was variant in our research on basis of the method and had spectra from $3.95 \pm 0.16$ to $9.67 \pm 2.8 \mathrm{mg} / \mathrm{ml}$ that soxhelet because of exerting heating might have reduced the antioxidant activity. It's interesting that situation of cultivating has impression on antioxidant activity. Therefore, previous researchers by comparing DPPH activity of 12 cornelian cherry that farmed by various cultivars achieved DPPH score from $3.30 \pm 0.20$ to $9.54 \pm 0.32 \mathrm{mg} / \mathrm{ml}$ and our finding is included in this spectra [22]. DPPH activity of various types of cherries are different. Melicháčová, $\mathrm{S}$ et al. have investigated total antioxidant activity of tart cherry and sweet cherry, they found that tart cherries possess 5.4 to $9.9 \mathrm{mg} / \mathrm{ml}$ DPPH inhibition potency. It's noticeworthy that $\mathrm{IC}_{50}$ score was achieved in our study had spectra from $4.70 \pm 123$ to $8.13 \pm 8.9 \mathrm{mg} / \mathrm{ml}$ that is consistent with reported $\mathrm{IC}_{50}$ [23].

Simonian, S conducted research about FRAP activity of cornelian cherry, and they reported $235 \mu \mathrm{mol} / \mathrm{g}$ FRAP activity for this fruit that is in accord of our result [24]. In this experiment FRAP activity have spectra from 180 to $190 \pm 40 \mu \mathrm{mol} / \mathrm{g}$, that is partially consistent with previous research. In addition, Ferric reducing ability of tart cherry has investigated by previous researcher and a number of pacific Northwest sour cherries in relation to FRAP activity was compared, it was found that Prenus cerasus with score $182.8 \pm 0.45 \mu \mathrm{mol} / \mathrm{g}$ can reduce ferric, this result is in accord of our result with spectra from 170 to $200 \mu \mathrm{mol} / \mathrm{g}$ FRAP activity [25].

By comparing extraction approaches, it can be deduced that for analyzing TPC, shaking incubator and ultrasonic with higher score of TPC are more efficient methods than soxhelet and. It's notice worthy that although $40^{\circ} \mathrm{C}$ is applied for $24 \mathrm{~h}$ in shaking incubator approach, the heat that is increased to $80^{\circ} \mathrm{C}$ during soxhelet for about $2 \mathrm{~h}$ in this procedure may degrade more phenolics and the efficiency might be decreased. Moreover, for analyzing DPPH, shaking incubator extract with the lowest rate of DPPH score could save the antioxidant activity of fruits more than other methods. However, soxhelet with highest rate of DPPH in fruits is the least efficient method for analyzing antioxidant activity. While there wasn't so much difference in FRAP score with different extraction methods in cornelian cherry, FRAP score that was achieved by ultrasonic procedure was the highest in Prunus cerasus.

\section{Conclusion}

To sum up, between three methods of extraction shaking incubator and ultrasonic procedure were more efficient for evaluating total phenolic compounds and antioxidant activity. Moreover, by applying two methods of antioxidant activity analysis, it is concluded that there isn't considerable difference among cornelian cherry and tart cherry antioxidant activity due to fact that by DPPH test tart cherry exhibited stronger antioxidant activity, but cornelian cherry had more potent antioxidant activity via FRAP test .It's notice worthy that although p-Coumaric acid content also is higher in tart cherry, total phenolic content is slightly higher in cornelian cherry.

\section{References}

[1] Mamedov, N. and Craker, L. (2002) Cornelian Cherry: A Prospective Source for Phytomedicine. XXVI International 
Horticultural Congress: The Future for Medicinal and Aromatic Plants.

[2] Reich, L., et al. (1996) Cornelian Cherry from the Shores of Ancient Greece. The Magazine of the Arnold Arboretum, 56, 2-7.

[3] Krośniak, M., et al. (2010) Cornelian Cherry (Cornus mas L.) Juices as a Source of Minerals in Human Diet. Journal of Toxicology and Environmental Health, Part A, 73, 1155-1158. http://dx.doi.org/10.1080/15287394.2010.491408

[4] Hassanpour, H., et al. (2011) Antioxidant Capacity and Phytochemical Properties of Cornelian Cherry (Cornus mas L.) Genotypes in Iran. Scientia Horticulturae, 129, 459-463. http://dx.doi.org/10.1016/j.scienta.2011.04.017

[5] Capanoglu, E., et al. (2011) Procyanidins in Fruit from Sour Cherry (Prunus cerasus) Differ Strongly in Chainlength from Those in Laurel Cherry (Prunus lauracerasus) and Cornelian Cherry (Cornus mas). Journal of Berry Research, 1, 137-146.

[6] Yilmaz, K.U., et al. (2009) Preliminary Characterisation of Cornelian Cherry (Cornusmas L.) Genotypes for Their Physico-Chemical Properties. Food Chemistry, 114, 408-412. http://dx.doi.org/10.1016/j.foodchem.2008.09.055

[7] Jayaprakasam, B., et al. (2006) Amelioration of Obesity and Glucose Intolerance in High-Fat-Fed C57BL/6 Mice by Anthocyanins and Ursolic Acid in Cornelian Cherry (Cornus mas). Journal of Agricultural and Food Chemistry, 54, 243-248. http://dx.doi.org/10.1021/jf0520342

[8] Tural, S. and Koca, I. (2008) Physico-Chemical and Antioxidant Properties of Cornelian Cherry Fruits (Cornus mas L.) Grown in Turkey. Scientia Horticulturae, 116, 362-366. http://dx.doi.org/10.1016/j.scienta.2008.02.003

[9] Schuster, M., et al. (2011) Interspecific Hybridization in Sweet and Sour Cherry Breeding. XIII Eucarpia Symposium on Fruit Breeding and Genetics.

[10] Ferretti, G., et al. (2010) Cherry Antioxidants: From Farm to Table. Molecules, 15, 6993-7005. http://dx.doi.org/10.3390/molecules15106993

[11] Mulabagal, V., Lang, G.A., DeWitt, D.L., Dalavoy, S.S. and Nair, M.G. (2009) Anthocyanin Content, Lipid Peroxidation and Cyclooxygenase Enzyme Inhibitory Activities of Sweet and Sour Cherries. Journal of Agricultural and Food Chemistry, 57, 1239-1246. http://dx.doi.org/10.1021/jf8032039

[12] Wang, H.B., Nair, M.G., Strasburg, G.M., Booren, A.M. and Gray, J.I. (1999) Novel Antioxidant Compounds from Tart Cherries (Prunus cerasus). Journal of Natural Products, 62, 86-88. http://dx.doi.org/10.1021/np980268s

[13] Ataie-Jafari, A., Hosseini, S., Karimi, F. and Pajouhi, M. (2008) Effects of Sour Cherry Juice on Blood Glucose and Some Cardiovascular Risk Factors Improvements in Diabetic Women: A Pilot Study. Nutrition \& Food Science, 38, 355-360. http://dx.doi.org/10.1108/00346650810891414

[14] Šarić, A., Sobočanec, S., Balog, T., Kušić, B., Šverko, V., Dragović-Uzelac, V., et al. (2009) Improved Antioxidant and Anti-Inflammatory Potential in Mice Consuming Sour Cherry Juice (Prunus cerasus cv. Maraska). Plant Foods for Human Nutrition, 64, 231-237. http://dx.doi.org/10.1007/s11130-009-0135-y

[15] Tall, J.M. and Raja, S.N. (2004) Dietary Constituents as Novel Therapies for Pain. The Clinical Journal of Pain, 20, 19-26. http://dx.doi.org/10.1097/00002508-200401000-00005

[16] Traustadóttir, T., Davies, S.S., Stock, A.A., Su, Y.L., Heward, C.B., Roberts II, L.J. and Harman, S.M. (2009) Tart Cherry Juice Decreases Oxidative Stress in Healthy Older Men and Women. The Journal of Nutrition, 139, 1896-1900. http://dx.doi.org/10.3945/jn.109.111716

[17] Kuehl, K.S., Perrier, E.T., Elliot, D.L. and Chesnutt, J.C. (2010) Research Article Efficacy of Tart Cherry Juice in Reducing Muscle Pain during Running: A Randomized Controlled Trial. Journal of the International Society of Sports Nutrition, 7, 17. http://dx.doi.org/10.1186/1550-2783-7-17

[18] Connolly, D., McHugh, M. and Padilla-Zakour, O. (2006) Efficacy of a Tart Cherry Juice Blend in Preventing the Symptoms of Muscle Damage. British Journal of Sports Medicine, 40, 679-683. http://dx.doi.org/10.1136/bjsm.2005.025429

[19] Gunduz, K., Saracoglu, O., Özgen, M. and Serce, S. (2013) Antioxidant, Physical and Chemical Characteristics of Cornelian Cherry Fruits (Cornus mas L.) at Different Stages of Ripeness. Acta Scientiarum Polonorum-Hortorum Cultus, 12, 59-66.

[20] Ferretti, G., Neri, D. and Bacchetti, T. (2014) Effect of Italian Sour Cherry (Prunus cerasus L.) on the Formation of Advanced Glycation End Products and Lipid Peroxidation. Food and Nutrition Sciences, 5, 1568-1576. http://dx.doi.org/10.4236/fns.2014.516170

[21] Kim, D.-O., Heo, H.J., Kim, Y.J., Yang, H.S. and Lee, C.Y. (2005) Sweet and Sour Cherry Phenolics and Their Protective Effects on Neuronal Cells. Journal of Agricultural and Food Chemistry, 53, 9921-9927. http://dx.doi.org/10.1021/jf0518599

[22] Rop, O., Mlcek, J., Kramarova, D. and Jurikova, T. (2010) Selected Cultivars of Cornelian Cherry (Cornus mas L.) as a New Food Source for Human Nutrition. African Journal of Biotechnology, 9, 1205-1210. 
[23] Melicháčová, S., Timoracká, M., Bystrická, J., Vollmannová, A. and Čéry, J. (2010) Relation of Total Antiradical Activity and Total Polyphenol Content of Sweet Cherries (Prunus avium L.) and Tart Cherries (Prunus cerasus L.). Acta Agriculturae Slovenica, 95, 21-28. http://dx.doi.org/10.2478/v10014-010-0003-3

[24] Badalica-Petrescu, M., Dragan, S., Ranga, F., Fetea, F. and Socaciu, C. (2014) Comparative HPLC-DAD-ESI (+) MS Fingerprint and Quantification of Phenolic and Flavonoid Composition of Aqueous Leaf Extracts of Cornus mas and Crataegus monogyna, in Relation to Their Cardiotonic Potential. Notulae Botanicae Horti Agrobotanici Cluj-Napoca, 42, 9-18. http://dx.doi.org/10.15835/nbha4219270

[25] Simonian, S. (2000) Anthocyanin and Antioxidant Analysis of Sweet and Tart Cherry Varieties of the Pacific Northwest. 